\title{
Ethnomedicinal uses of some legumes in Tripura, India
}

\author{
Somnath Kar' ${ }^{1}$, Dipti Das², Aparajita Das ${ }^{3}$, and B. K. Datta ${ }^{3}$ \\ ${ }^{1}$ Communicating author: Department of Botany Holy Cross College, Lembucherra, 799210, Tripura, India \\ E-mail: somnathagt21@gmail.com \\ ${ }^{2}$ Department of Botany, Netaji Subhash Mahavidyalaya, Udaipur, 799114, Tripura, India \\ ${ }^{3}$ Plant Taxonomy and Biodiversity Laboratory, Department of Botany, Tripura University, Suryamaninagar \\ 799022, Tripura, India
}

[Received 13.12.2019; Revised 15.12.2019; Accepted 17.12.2019; Published 31.12.2019]

\begin{abstract}
The use of medicinal plants constitute a significant resource base of the traditional communities for their daily healthcare. This study summarized their current knowledge on medicinal uses of locally available leguminous plants. Collected data showed their wide range uses including antidiarrhoeal, antimicrobial, antihypertensive, anti-inflammatory, analgesic, anti-plasmodial, antihelminthic, etc. The present paper recorded the traditional medicinal uses of 35 plant species belonging to 26 genera of Leguminosae along with their distribution, local names and availability.
\end{abstract}

Key words: Leguminosae, Ethnomedicine, Tripura.

\section{INTRODUCTION}

Tripura, a small hilly state of North-Eastern India, spread over $10,491.69 \mathrm{~km}^{2}$. It is the thirdsmallest among the 28 states in the country. It extends from $22^{\circ} 56^{\prime} \mathrm{N}$ to $24^{\circ} 32^{\prime} \mathrm{N}$ and $91^{\circ} 09^{\prime}$ E to $92^{\circ} 20^{\prime}$ E. Its maximum extent measures about $184 \mathrm{~km}$ from North to South, and $113 \mathrm{~km}$ East to West. Tripura is bordered by Bangladesh to the west, north and south; the Indian states of Assam to the north-east; and Mizoram to the east. In 2011 the state had 3,671,032 residents, constituting $0.3 \%$ of the country's population (Kar \& Datta 2015). The tribal population comprises several different ethnic groups with diverse languages and cultures. There are 20 ethnic groups namely Tripuri, Jamatia, Reang, Noatia, Chakma, Bhil, Bhutia, Chaimal, Garo, Halam, Khasia, Kuki, Lepcha, Lushai, Mog, Munda/ Kaur, Orang, Santhal, Uchai \& Generic tribes (TRCIT 2019). Among them, Tripuri and Reang are the major groups (Majumdar \& Datta 2007). The tribal people on natural habitats hold incredible traditional knowledge on the use of various plant/ forest resources (Majumdar et al. 2006).

The Leguminosae is one of the largest flowering plants families having around 751 genera and 19,500 species round the world (Lewis et al. 2005; LPWG 2013). In terms of economic importance, Leguminosae is the most important Dicotyledonous family (Harborne 1994). In providing food crops for world agriculture legumes are second only to the Grasses (cereals) (Graham \& Vance 2003). In comparison to cereal grains the seeds of Legumes are richer in high quality proteins. These are not only used as food-crops, forages and green manures but a wide range of natural products such as flavours, drugs, poisons and dyes are also produced from leguminous plants.Its members yield nutritious food, fibre, shelter, valuable medicines and also virulent poisons (Datta \& Mukherji 1952). The members exhibit most varied properties, some are amylaceous, other oleaginous, many yield resins, balsams and dyes, a 
few are astringent, acrid and bitter, narcotic and poisonous, emetic and purging, tonic and restorative. The seeds are often anti periodic and the root is anthelminthic (Sharma \& Kumar 2013). The present study is thus an attempt to document different medicinal legumes of Tripura used by local healers to cure different ailments.

\section{METHODOLOGY}

Several field surveys were conducted in different parts of Tripura during 2015 - 2018 in different seasons of the year and ethnomedicinal information were collected from local medicine-men and elderly people. The main places include Khowai in West Tripura, Dhalai, Sepahijala, North Tripura and Gomati district during the year 2015-2018 following Jain (1989) and Jain and Mudgal (1999) and covered all seasons almost in all study sites. For authentic identification of the collected plants, various treaties were consulted viz. Prain (1903), Deb (1981) and Kanjilal et al.(1938). For updated nomenclature www.worlfloraonline.org and www.theplantlist.org were regularly consulted. The voucher specimens were processed into mounted Herbarium-sheet following Jain \& Rao (1977). During this survey, detailed ethno-medico-botanical information on different plants, plant part used, uses and diseases treated were recorded from the local people of different tribal communities were recorded. Mainly the elderly women, ochais and the vaidyas were consulted. Direct observation, casual interaction and structured interviews were adopted to collect valid information. Voucher specimens have been cited for all the species enumerated in the table. Herbarium specimens have been deposited in Herbarium of the Botany Department of Tripura University.

\section{RESULTS}

The survey recorded 35 species of leguminous plants and are enumerated below along with their scientific name, local name, distribution, habit, part used, availability and uses.

Acacia farnesiana (L.) Willd.,Sp. Pl. 4: 1083. 1806. [Mimosoideae]

Local name: Wilfa (Tripuri), Amachukai (Noatia), Kantanaksha (Chakma)

Distribution: Jampui, Khowai \& West Tripura; common

Habit: Tree

Plant parts used:Leaf, stem, bark and flower.

Uses: Bark juice is taken to stop vomiting or urge to vomit. Teeth brushed with a branch reduce toothache and strengthens gums. Fresh leaf-paste is rubbed on forehead to reduce the headache.

Abrus precatorius L., Syst. Nat., ed. 12, 2: 472. 1767. [Papilionoideae]

Local name:Takharichum (Tripuri), Jesthomodhu (Jamatia), Besko (Reang)

Distribution: Scattered, throughout the state; common

Habit: Shrubby climber

Plant part used: Root, seed, leaf

Uses: Paste of roots, seeds and leaves usedagainst joint, muscular and abdominal pain, poisonous bites.

Adenanthera pavonina L., Sp. Pl. 1: 384. 1753. [Mimosoideae]

Local name: Be Ai (Lusai), Rakta-chandan, Chandan-bichi (Bengali) 


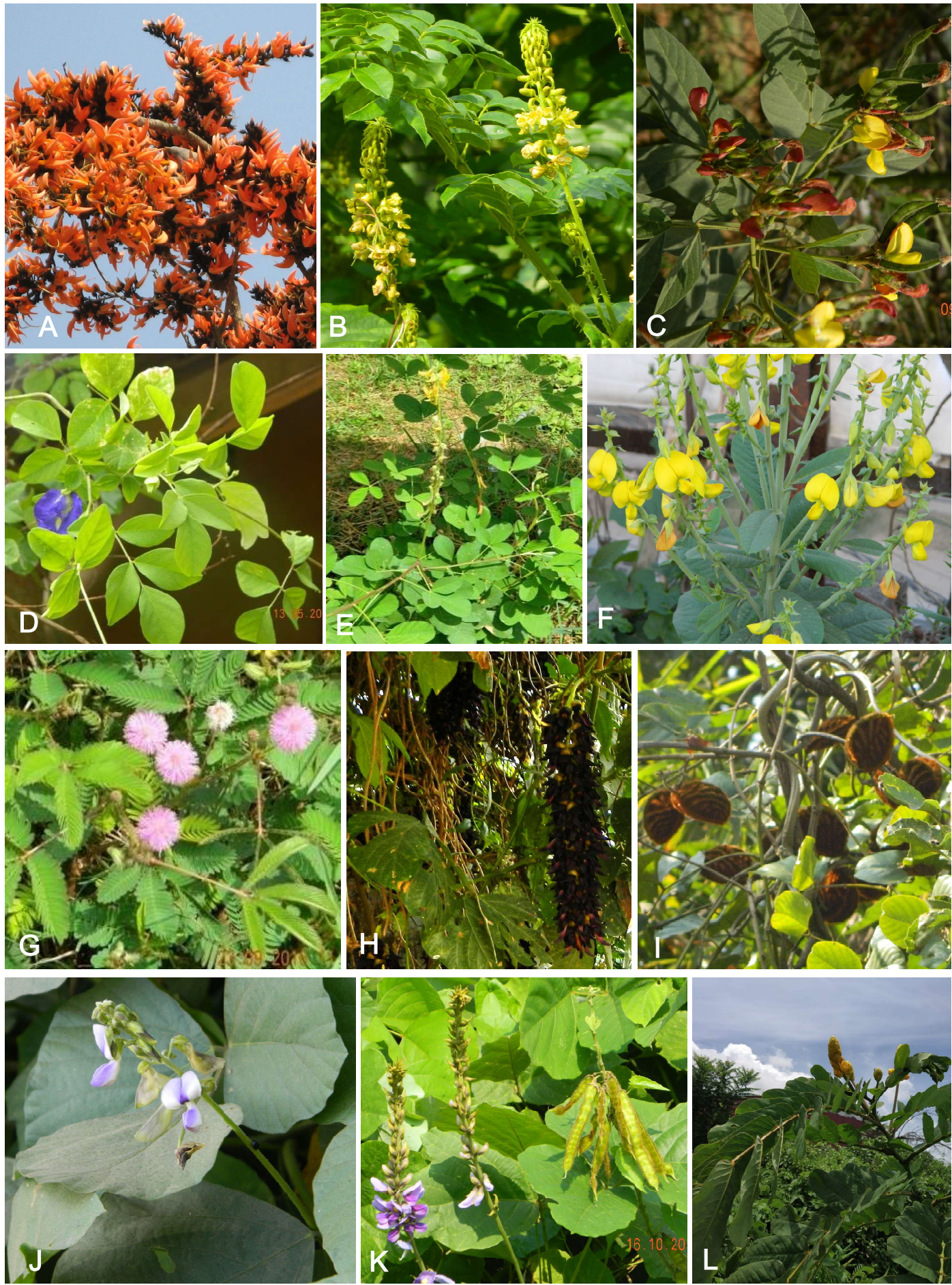

PLATE - I. Some leguminous ethnomedicinal plants of Tripura: A. Butea monosperma; B. Caesalpinia bonduc; C. Cajanus cajan; D. Clitoria ternatea; E. Crotalaria pallida; F. Crotalaria spectabilis; G. Mimosa pudica; H. Mucuna bracteata; I. Mucuna monosperma; J. Pueraria phaseoloides; K. Pueraria montana var. lchinensis; L. Senna alata 
Distribution: Throughout the state; commonly planted

Habit: Tree

Plant part used: Bark, leaf, seed

Uses: Barks are used for arthritis; leaf-decoction usedto reduce burning sensation; seeds are used in fever and diarrhea.

Albizia lebbeck (L.) Benth., London J. Bot. 3: 87. 1844. [Mimosoideae]

Local name: Kalma (Santal), Khuraibufang (Tripuri), Koroi (Jamatia)

Distribution: Throughout the state; common

Habit: Tree

Plant part used: Bark

Uses: Barks are used for the treatment of bronchitis and piles.

Albizia procera (Roxb.) Benth., London J. Bot. 3: 89. 1844. [Mimosoideae]

Local name: Sadakoroi (Jamatia), Silkori (Chakma)

Distribution: Scattered throughout the state; less common

Habit: Tree

Plant part used: Bark

Uses: Bark-decoction is given in rheumatism, haemorrhage, problems of pregnancy and in stomach-ache.

Bauhinia acuminata L., Sp. P1. 1: 376. 1753. [Caesalpinioideae]

Local name: Sadakanchan (Bengali), SadaKadam (Chakma), Nereng Bai (Mog), Khuntaosa (Tripura)

Distribution: Throughout the state; common ornamental

Habit: Shrub

Plant part used: Bark, leaf, seed

Uses: Paste of barks, seeds \& leaves are used for arthritis, gout, vomiting, fever, hemorrhoids and diarrhea.

Butea monosperma (Lam.) Taub., Nat. Pflanzenfam. [Engler \& Prantl] 3(3): 366. 1894. [Papilionoideae]

Local name: Palash (Bengali), Jong-obi (Tripuri)

Distribution: Scattered throughout the state; less common

Habit: Tree

Plant part used: Flower, root, bark

Uses: Paste of flowers and barks are used against dysentery, toothache and wound. Roots are used to treat elephantiasis, herpes and night blindness.

Caesalpinia bonduc (L.) Roxb., Fl. Ind., ed. 1832, 2: 362. 1832. [Caesalpinioideae]

Local name: Jhogragota (Tripuri), Kumujjaludi (Chakma), Achonangri (Mog) Jhograguta (Bengali)

Distribution: Dhalai, South \&West Tripura; common

Habit: Shrubby climber, much prickly

Plant part used: Seeds. 
Uses: Extract of seed-coat used as anti-inflammatory and as analgesic. Seed extract is claimed to be purgative, anti-helminthic, anti-inflammatory, and used for treatment of malaria, colic, skin diseases, leprosy, febrifuges and specific in the treatment of hydrocele. The oil from the seeds is used in convulsions and paralysis.

Cajanus cajan (L.) Millsp., Publ. Field Columb. Mus., Bot. Ser. 2(1): 53. 1900. [Papilionoideae]

Local name: Bethliang (Darlong), Khokhleng (Jamatia, Halam), Arol (Bengali), Bethwi (Hrangkhawl), Muimasing (Tripuri, Debbarma)

Distribution: Throughout the state; abundant

Habit: Shrubby annual

Plant part used: Leaf

Uses: Tender leaves are used for treating jaundice, osteoporosis, inflammation, fracture and heart diseases and that also improves immunological functions.

Cassia fistula L., Sp. P1. 377. 1753. [Caesalpinioideae]

Local name: Sonal, Bandarlati (Bengali), Hounar (Noatia), Swkalthuri (Darlong)

Distribution: Scattered throughout the state; common

Habit: Tree

Plant part used: Leaf, seed, bark

Uses: Pastes of leaves, seeds and barks are used against constipation, flatulence, inflammation and wounds

Clitoria ternatea L., Sp. Pl. 753. 1753. [Papilionoideae]

Local name: Aparajita (Bengali), Khumwakhak (Noatia)

Distribution: Scattered throughout the state; common in gardens

Habit: Climber

Plant part used: Root, seed, leaf

Uses: Pastes of root, seeds andleaves are used for treating constipation, mental disorder and also as memory enhancer.

Crotalaria pallida Aiton, Hort. Kew. 3: 20. 1789. [Papilionoideae]

Local name: Ban Atasi (Bengali), Bishut, Skamyouhmakakho( Reang), Kudugjhunjhuni (Chakma) Bishut (Santal), Chowly (Tripuri )

Distribution: Throughout the state; common

Habit: Undershrub

Plant part used: Root, seed, leaf

Uses: Pastes of roots and leaves are used to treat swelling of body, indigestion, bone injury and seeds are used to treat rheumatism.

Crotalaria spectabilis Roth, Nov. P1. Sp. 341. 1821. [Papilionoideae]

Local name: Jhunjhania (Noatia), Mwswigogora (Tripuri), Kudukjhunjhuni (Chakma) Atasi (Bengali)

Distribution: Scattered throughout the state; common

Habit: Undershrub

Plant part used: Whole plant, leaf 
Uses: Whole-plant extract is used to treat impetigo, scabies, intestinal worms, and is an antiseptic for wounds. Leaf-paste is used for the treatment of poisonous snake bites and centipede stings. Leaf-juice is used to treat tetanus. Leaves are also used for treating rheumatism and piles.

Desmodium gangeticum (L.) DC., Prodr. 2: 327. 1825. [Papilionoideae]

Local name: JutaSalpani (Tripuri), Kangchan (Darlong), Kangchema (Halam)

Distribution: West, North and South Tripura; abundant

Habit: Undershrub

Plant part used: Leaf

Uses: Leaf-paste is applied on the affected areas for the treatment of tumors.

Entada phaseoloides (L.) Merr., Philipp. J. Sci., C 9: 86. 1914. [Mimosoideae]

Local name: Poi (Darlong), Gila (Tripuri), Gilatak (Chakma), Swkwi-bakhla (Debbarma)

Distribution: Scattered throughout the state; less common

Habit: Liana

Plant part used: Seed

Uses: Seed powders are used for treating mumps.

Mimosa pudica L., Sp. P1. 518. 1753. [Mimosoideae]

Local name: Tonthi Chhoitemara, Samsoti (Rupini), Chwkbramon (Hrangkhawl)

Lajuriher (Chakma)

Distribution: Throughout the state; very common

Habit: Annual undershrub

Plant part used: Root, leaf.

Uses: Root-juice is used in toothache. Leaf- paste is used on boils.

Mucuna bracteata DC. ex Kurz, J. Asiat. Soc. Bengal, Pt. 2, Nat. Hist. 42: 231. 1873. [Papilionoideae]

Local name: Bomppylat (Tripuri), Burirlata (Bengali)

Distribution: Scattered throughout the state; less common

Habit: Climber

Plant part used: Root, seed and leaf

Uses: Roots are useful against nephropathy, elephantiasis, dropsy, fever and deliria. Leafdecoction is used for ulcer. Seeds are used to treat Parkinson's disease, arthritis and kidney problems.

Mucuna monosperma DC. ex Wight, Bot. Misc. 2(6): 346, suppl. t. 12. 1831. [Papilionoideae]

Local name: Militari Lata (Bengali), Sanchu (Tripuri), Thunka (M), Chabina (Reang), Tong-fai (Uchai)

Distribution: Gomati \& South Tripura; less common

Habit: Shrubby climber

Plant part used: Root, leaf

Uses: Roots are applied to cure glaucoma, eczema and scabies. Leaf-paste is applied to check bleeding from cuts and wounds and also to treat bone fracture . 
264 Ethnomedicinal uses of legumes in Tripura

Mucuna pruriens (L.) DC., Prodr. 2: 405. 1825. [Papilionoideae]

Local name: Alakushi, banariola (Bengali), Bamphe (Tripuri), Bilaiachhara (Chakma)

Distribution: Scattered throughout the state; common

Habit: Shrubby climber

Plant part used: Leaf, seed

Uses: Leaf-decoction is used on boils and scabies. Leaf-paste is also applied on cuts and wounds. Dry seed powder are used to check intestinal worms.

Neptunia oleracea Lour., Fl. Cochinch. 2: 654. 1790. [Mimosoideae]

Local name: Panilajuk (Bengali), Kharai (Tripuri); Twijhongcha ( Hrangkhawl), Thorai Haa (Noatia)

Distribution: Khowai, North \&West Tripura; common in wetlands

Habit: Annual floating herb

Plant part used: Whole plant

Uses: The whole plant juice is used as tonic to treat jaundice and gastric troubles.

Parkia timoriana (DC.) Merr., Sp. Blancoanae 169. 1918. [Mimosoideae]

Local name: Sapota, Kukitetai, Wakrea (Tripuri), Rongta (Darlong)

Distribution: Scattered throughout the state

Habit: Tree [Naturalised \& planted]

Plant part used: Fruit, flower, leaf

Uses: Paste of fruits, flowers and leaves used in dysentery, indigestion and diarrhea.

Phyllodium pulchellum (L.) Desv., J. de Botanique, Appliqueel'Agriculture, a la Pharmacie, a la Medecine et aux Arts, 1813. [Papilionoideae]

Local name: JutaSalpani (Tripuri), Kangchan (Darlong), Kangchema (Halam)

Distribution: Scattered throughout the state; common

Habit: Shrub

Plant part used: Leaf, root

Uses: Decoction of dried leaves used in colds and fever. Roots used for malaria, swelling and enlargement of liver and spleen, rheumatism, bone pains, swelling due to contusion or sprain and excessive menstrual flow.

Pongamia pinnata (L.) Pierre, Fl. Forest. Cochinch. sub t. 385. 1899. [Papilionoideae]

Local name: Karanga (Bengali), Patia (Tripuri)

Distribution: Khowai \& West Tripura; abundant

Habit: Tree

Plant part used: Bark

Uses: Bark infusion is used during blood dysentery.

Pueraria montana var. chinensis (Ohwi) Sanjappa \& Pradeep, Legumes India 288. 1992. [Papilionoideae]

Local name: Aidot tang alu (Tripuri)

Distribution: Scattered throughout the state; less common 
Habit: Climber

Plant part used: Root tuber, leaf \& flowers

Uses: Roots are used in fever, influenza, headache etc. Leaves are used to treat snake bites. A decoction of the flowers and tubers is used to treat alcoholism, diarrhea, dysentery, acute intestinal obstruction, digestive problem, febrifuge, hypoglycemia, hypertension, heart disease and migraine. The flowers and the roots are also antidote, antiemetic, antipyretic, and antispasmodic.

Pueraria phaseoloides (Roxb.) Benth., J. Linn. Soc., Bot. 9: 125. 1867. [Papilionoideae]

Local name: Lubia (Tripura), Muiprey (Chakma)

Distribution: Throughout the state; common

Habit: Herbaceous climber

Plant part used: Roots

Uses: Roots are used for hypothermic, spasmolytic, hypotensive and antiarrhythmic treatment

Pueraria tuberosa (Roxb. ex Willd.) DC., Ann. Sci. Nat. (Paris) 4: 97. 1825. [Papilionoideae]

Local name: Thakhakchang (Reang)

Distribution: Scattered throughout the state; less common

Habit: Climber

Plant part used: Stem

Uses: Sap of the stem is applied to cuts to stop hemorrhages.

Saraca asoca (Roxb.) Willd., Blumea 15: 393. 1968. [Caesalpinioideae]

Local name: Ashok (Bengali), Khumbaikang, Moma/ Pingal (Chakma)

Distribution: Dhalai, West \& South Tripura; often planted

Habit: Tree

Plant part used: Leaf and bark

Uses: Paste of young leaves and barks are used in skin diseases and menstruation pain.

Senna alata (L.) Roxb., Fl. Ind. 2: 349. 1832. [Caesalpinioideae]

Local name: Dadukung (Darlong), Danduraja (Tripuri), Dokdoraja (Jamatia)

Thechou (Halam)

Distribution: Scattered throughout the state; very common

Habit: Shrub

Plant part used: Leaf

Uses: Leaf-paste is used inskin infection including ringworm.

Senna occidentalis (L.) Link, Handbuch 2: 140. 1829. [Caesalpinioideae]

Local name: Muitalbe (Noatia), Kalkasunde (Bengali), Ka-jabaong (Mog), Rotha

(Tripuri), Dangordattlong (Chakma)

Distribution: Throughout the state; common

Habit: Herb

Plant part used: Leaf and root 
266 Ethnomedicinal uses of legumes in Tripura

Uses: Leaf-paste is used in skin infection and constipation. Root-decoction is used in urinary disorder; seeds are useful in cough.

Senna sophera (L.) Roxb., Fl. Ind. 2: 347. 1832. [Caesalpinioideae]

Local name: Kashimda (Tripuri), Chotokalkasunde (Bengali), Moitarabek (Mog)

Distribution: Throughout the state; common

Habit: Herb

Plant part used: Bark

Uses: Bark is used to treat respiratory disorders.

Senna tora (L.) Roxb., Fl. Ind. 2: 340. 1832. [Caesalpinioideae]

Local name: Mailwma (Rupini), Dangii( Mog), Chavuka (Malsom), Luthamphang (Reang)

Distribution: Throughout the state; abundant

Habit: Herb

Plant part used: Leaf

Uses: Leaf-paste is are used in skin diseases.

Sesbania grandiflora (L.) Pers., Syn. P1. 2(2): 316. 1807. [Papilionoideae]

Local name: Bakphul (Bengali), Bogful (Halam)

Distribution: Scattered throughout the state; commonly planted

Habit: Small tree

Plant part used: Leaf, bark

Uses: Leaf-extract is useful in cough. Bark-paste is used in the treatment of pox.

Spatholobus parviflorus (DC.) Kuntze, Revis. Gen. Pl. 1: 205. 1891. [Papilionoideae]

Local name: Mroie (Tripuri)

Distribution: Scattered throughout the state; less common

Habit: Climber

Plant part used: Leaf, stem

Uses: Leaf and stem juices are applied for bone fracture.

Tadehagi triquetrum (L.) H.Ohashi, Ginkgoana 1: 290.1973. [Papilionoideae]

Local name: Rulimatakher (Chakma), Jurimandakher (Darlong), Blongmykongda (Tripuri)

Distribution: Scattered throughout the state; common

Habit: Undershrub

Plant part used: Root

Uses: Root juices used for treating urinary problems, stomach ache, diarrhea

Tamarindus indica L., Sp. Pl. 1: 34. 1753. [Caesalpinioideae]

Local name: Thentrwi (Tripuri), Tedoy (Chakma), Tengtroi (Darlong)

Distribution: Throughout the state; common

Habit: Tree 
Plant part used: Fruit and leaf

Uses: Leaf-paste is used for treating headache. Ripe fruits are taken for treating headache and high blood-pressure. Leaf-juice is taken as remedy for burning sensations during urination. Young leaves are boiled in water and the water is consumed to treat dysentery.

\section{DISCUSSION}

The ethnomedicinal uses of 35 species of Leguminosae have been recorded from different parts of the state of Tripura. At the subfamily level those are represented as Caesalpinioideae 09 spp., Mimosoideae 08 spp. and Papilionoideae 18 spp. and are representing 26 genera. Of these species 17 are scattered throughout the state, 11 are distributed throughout the state, 2 species are from Dhalai, South and West Tripura, 1 species to Jampui, Khowai \& West Tripura, 1 species to Gomati and South Tripura, 1 species to Khowai and West Tripura, 1 species to Khowai, North \& West Tripura and 1 species to West, North and South Tripura.

The habit-type of the recorded ethnobotanical species are different, which includes climbers (11 spp.) and trees (11 spp.) are more frequently used in traditional medicine preparations as compared to undershrubs (5 spp.), herbs (4 spp.) and shrubs (4 spp.) (Figure 1).

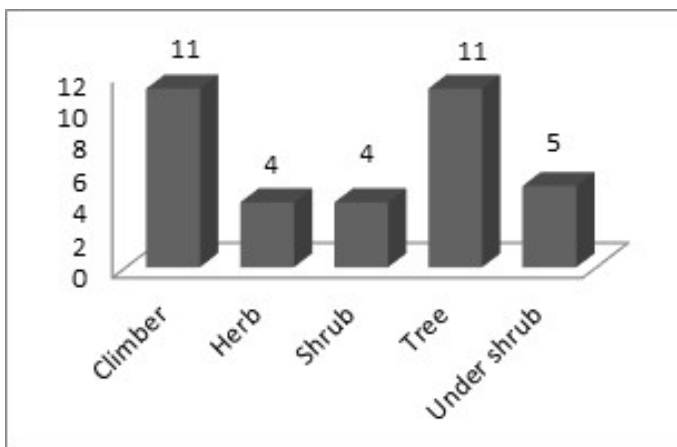

Figure 1. Distribution of plant species across various life forms

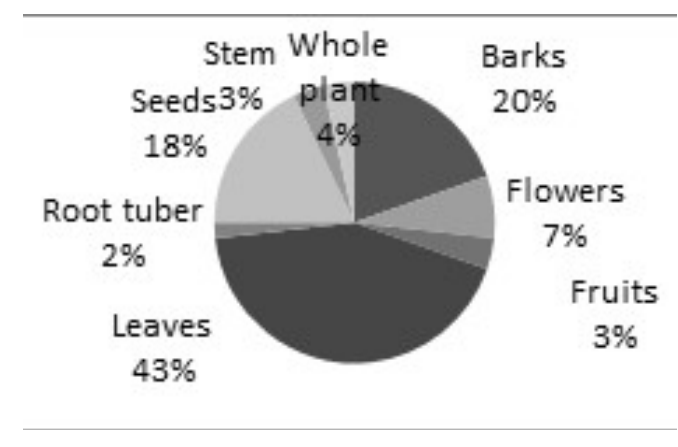

Figure 2. Utilization of plant parts used for treatment of different diseases

Considering the plant-parts in use shows: leaves (43\%), barks (20\%), seeds (18\%), flower (7\%), whole plants (4\%), fruits (3\%) stem (3\%) and root tuber (2\%). Medicines are administeredin different forms like extract, juice, decoction, infusion and paste for management of various ailments.

The general health problem such as jaundice, diarrhoea, urinal problem, gastric, dysentery, bone fracture, skin disease, toothache, fever, treatment of arthritis, allergy, vomiting, stoma- ache, urinal problems, coughing, nephropathy, elephantiasis, dropsy are the most common ailments recorded during the investigation. This study indicates that the ethnic people of studied areas have acquired considerable knowledge about the medicinal uses of different leguminous plants in their surroundings, and in their daily life to remain healthy. Analysis of collected information also revealed that most of plants are collected form their wild habitat except very few are grown in their home-gardens, e.g. Adenanthera pavonina, Bauhinia acuminata, Cajanus cajan, Clitoria ternatea, Parkia timoriana, Saraca asoca, Sesbania grandiflora, and Tamarindus indica. Most of the recorded plants are used against more than one diseases by the traditional people of Tripura. However, most of these are easily available and are not marketed in the area to use as medicinal plants. 


\section{Acknowledgements}

Authors are thankful to the Head, Department of Botany, Tripura University for providing all facilities during work.

\section{LITERATURE CITED}

Datta, S.C. \& Mukherjee, B. 1952. Pharmacognosy of Indian leaf drugs. Government of India Ministry of Health, Government of India Press, Calcutta Bulletin No. 2, 103-116.

Deb, D.B. 1981. The Flora of Tripura state. Vols. 1. Today and Tomorrow's Printers and Publishers, New Delhi.

Graham, P.H. \& Vance, C.P. 2003. Legumes: Importance and Constraints to Greater Uses. Plant Physiology. 131: $872-877$.

Harborne, J.B. 1994. Phytochemistry of the Leguminosae. In: Bisby, F.A. et al. (eds.), Phytochemical Dictionary of the Leguminosae. Chapman \& Hall, London.

https://trci.tripura.gov.in/tribal_population

Jain, S.K. 1989. Methods and Approach in Ethnobotany. National Botanical Research Institute, Lucknow.

Jain, S.K. \& Rao, R.R. 1977. A Handbook of Field and Herbarium Methods. Today and Tomorrow's Printers and Publishers, New Delhi.

Jain, S.K. \&Mudgal, V.A. 1999. Handbook of Ethnobotany. Bisen Singh Mahendra Pal Singh, Dehradun.

Kanjilal, U.N.; Kanjilal, P.C. \& Das, A. 1938. Flora of Assam, Vol. 2, Assam Govt. Press, Shillong.

Kar, S. \& Datta, B.K. 2015. A glimpse of the traditional uses of plants by Koloi subtribe of Tripura. J. Bot.Soc. Bengal 69(2): $147-152$.

Lewis, G.P.; Schrire, B.D.; Mackinder, B. \& Lock, M. (eds.), 2005. Legumes of the World. Royal Botanic Gardens, Kew.

LPWG [Legume Phylogeny Working Group]. 2013. Legume phylogeny and classification in the $21^{\text {st }}$ Century: progress, prospects and lessons for other species-rich clades. Taxon. 62: $217-248$.

Majumdar, K. \& Datta, B.K. 2007. A study on ethno-medicinal usage of plants among the Tripuri tribes of Tripura state, India. Nat. Prod. Rad., NISCIR. (6): 68 - 72.

Majumdar, K.; Saha, R.; Datta, B.K.\& Bhakta, T. 2006. Medicinal plants prescribed by different tribal and non-tribal medicine man of Tripura State. Indian J. Trad. Knowl. 5(4): $559-562$.

Prain, D. 1903. Bengal Plants. Vol. I. West, Newman \& Co., London.

Sharma, M. \& Kumar, A. 2013. Leguminosae (Fabaceae) in Tribal Medicines. J. Pharma. Phytochem. 2(1): 276 - 283.

TRCIT 2019. Tribal Research and Cultural Institute,Tribal Welfare Department, Govt. of Tripura, Agartala.https://rci.tripura.gov.in/

www.theplantlist.org

www.worlfloraonline.org 